THE

IJOURNAL
Hong, Y-H. (2019). The ijournal 5, I, I4-

27. 10.33 I37/ijournal.v5il.33468

\title{
Towards Archival Justice: The Case of Nogŭn-ri Massacre During the Korean War Young-Hwa Hong
}

\section{Abstract}

This paper discusses the social production of archives with a focus on the archive of the Nogŭn-ri Massacre, a case of mass violence against South Korean civilians by US forces during the Korean War. Recent scholarship has criticized views of archives as stable repositories for documents, and instead has shown the process through which archives are constructed through divergent social forces. Moreover, scholars have encouraged archivists to actively function as conduits for the voices of marginalized counterpublics. The archive of the Nogŭn-ri Massacre itself is shown to have been formed by survivors and activists who demanded an apology and redress from the US military for the massacre. This counterpublic archive was first formed of oral testimony, but increasingly accumulated a growing number of written US military documents repurposed by the activists in the service of archival justice.

Keywords: Archives, Archival Justice, Societal Provenance, Archival Activism, Nogŭn-ri Massacre, Korean War 


\section{Introduction}

Archival literature concerning social justice has been rapidly growing since 2000, connecting archival work to the issues of structural and institutionalized oppression such as militarism and war, violations of civil liberties, colonialism, gender and ethnic inequities, and exploitative labour conditions (Duff et al, 2013; Wallace, 2017). Archivists advocating social justice issues also claim that archives are not simply neutral repositories of information and records. Rather, they are embedded in the unequal structures of power relations (Findly, 2016; Ketelaar 1999; Wallace 2017). In other words, archives are sites of hegemonic struggles just like any other social institution.

The struggle for social justice in the field of archival work requires examination of theoretical conceptualizations of social justice, and of the role of archives and archivists. In this vein, Derrida (1996) pointedly argues that "effective democratization can always be measured by this essential criterion: the participation in and the access to the archive, its constitution and its interpretation" (p.4). This means that archives should welcome citizen participation and offer free access for personal or collective purposes. Such openness to citizen participation should be seen as a fundamental principle of archival justice. This principle should be applied especially to voiceless people, such as victims of structural violence. It is important that the victims of such violence be allowed to participate in the creation of records and that the records should be available to the general public, including the victims themselves. As archival choices have long been determined based on unequal power relations, it is important to re-contextualize the records to represent the voice of the governed, as well as to utilize social provenance for an entire community of the marginalized. In this context, the role of archives also should be reconsidered. Rather than viewing them as a place for evidential records, one should treat them as a contested place for memory-building in relation to social agents and structures. As one of the social agents in creating and maintaining records, archivists are also expected to be conscious of such changes as well as of the societal significance and impact of archives.

This paper will focus on the archival memory of the Nogŭn-ri incident, a mass killing of civilians by American soldiers during the Korean War. One of many atrocities committed by the US and South Korean forces during the Korean War, its memory is complicated by the politics of Cold War South Korea and the United States, during which the very mention of atrocities committed by allies could expose one to accusations of collaboration with Communists - a potential death sentence in pre-1990s South Korea and an embarrassing accusation in the United States. Furthermore, the memory of the incident is shaped by an uneven and insufficient collection of "official archives" and the accusation by those who want to deny the incident of 
the politicization of the memory of the atrocity. It is at once a key flashpoint in the historical memory of the Korean War, a political fault-line in present-day South Korea, and a test-case for understanding the role of social justice in the activities of archivists.

The first section of this paper will explore theoretical concepts that are essential for establishing proper understanding of archival justice. Instead of looking at archives as things, I will discuss the role of archives as a process, and the importance of the concept of societal provenance as an alternative to traditional monolithic approaches to provenance. I will also explore the possibility for archives to emerge from a counterpublic sphere as tools for voiceless and marginalized communities. The second section will introduce a case study - the Nogŭn-ri massacre during Korean War - and discuss how archivists and activists in Korea have utilized social provenance for the survivors of the massacre.

\section{Theoretical Concepts for Archival Justice and Collective Memory}

Although the enthusiasm towards social justice in archival studies has been growing in recent years, Wallace (2017) and Duff et al (2013) have pointed out that the relationship between archives and social justice remains implicit and unsettled. Inspired by critical scholarship on archival justice (Cook, 1997; Douglas 2017; Duff et al, 2013; Findlay 2016; Flinn, 2011; Lee 2015; Nesmith 1999; Stoler, 2002), I suggest that the following three concepts - "archives-as-process," "societal provenance of archives," and "archives as counterpublic sphere" - are essential for reconstructing collective memory of the past on behalf of the socially marginalized such as the victims of the Nogŭn-ri massacre. By doing so, I attempt to avoid universalistic approaches to social justice as well as to contextualize the Nogŭn-ri incident in its evolving social and political context.

\section{Archives as a process}

According to the traditional understanding, archives were sites of knowledge retrieval, not organs of knowledge production (Stoler, 2002). Critical anthropologist Ann Stoler (2002) has coined the phrase "archives as a process," arguing that it is significant to pay attention to the archives' form and constitution rather than just the content of archives. For instance, colonial archives have selectively duplicated, disseminated and destroyed documents, while designating other documents "secret, very secret and confidential," even though the information so marked might be well-known to both the settlers and the colonized in the colonies themselves. They prevented transparency and public access, and instead operated as an organ of the colonial state. 
HONG | TOWARDS ARCHIVAL JUSTICE:THE CASE OF NOGǓN-RI MASSACRE DURING THE KOREAN WAR

It may also be argued that colonial archives themselves are the site of meaning making, which requires critical interpretations (Anderson, 2013). Thus, archives are the "spaces of memorypractices not primarily seeking the truth or searching the history, but transforming their experiences into meaning" (Ketelaar 2009 p.120).

Similarly, Duff and Harris (2002) argue that traditional archival arrangement and the description of records provide limited information concerning record creation and use. It is because "records are always in the process of being made, that 'their' stories are never ending and that the stories of those who are conventionally called records creators, records managers, archivists, users, and so on are parts of bigger stories understandable only in the ever-changing broader contexts of society" (p.265). Indeed, in the case of archives concerning Nogŭn-ri massacre, the original records were war records by American soldiers, which created tension with oral narratives of the victims. Following Stoler (2002) and Duff and Harris (2002), it is vital to understand the way such records are produced and to interpret the archives as a site of knowledge production in relation to power and public memory. Of course, memory is highly selective. When archives as houses of memories privilege certain records, they automatically silence other voices and reinforce unequal power relations (Cook 2013). Thus, the concept "archives-as-a-process" is helpful to open up spaces for the marginalized and to unpack the complexities of social memories and records towards archival justice.

\section{Societal provenance of archives}

Since the 1990s, critical archivists such as Cook (1997) and Nesmith (1999) have criticized the traditional interpretation of archival provenance that caused exclusion and alienation of the socially marginalized. For instance, Anderson (2013) demonstrates in her research that the authorship within colonial archives functions to maintain the hierarchical relationship between the colonizer and the colonized in Australia, and ultimately silences the voice of indigenous peoples. In current archival studies, fonds are no longer seen as having a relationship with a single creator. Rather, one must consider broader societal provenance and recognize that "the provenance of a given record or body of records consists of the social and technical processes of the records' inscription, transmission, which accounts for its existence, characteristics and continuing history" (Douglas 2017, p. 35; Nesmith 1999, p. 146). The concept of societal provenance encourages archivists to reflect on the broad spectrum of human experience (Cook 2013, p.110), to locate records creators within broader social and historical structures, and to consider various social actors as records creators.

Records creators do not act in social isolation, but are significantly influenced by various actors and actions over time (Douglas, 2017). Even colonial officials are in a relationship with 
the colonized as well as the colonial state, and the documents that they produce consequently reflect a wide range of social actors. Ideally, archives should actively embrace this reality, and deliberately expand their range to include the voices of diverse peoples. If one applies this to the Nogŭn-ri archive, one sees both the persistent presence of the voices of Nogŭn-ri victims even within the military archive and the necessity of deliberately including the oral narratives of Nogŭn-ri victims in the archive alongside the written military records.

\section{Archives as counterpublic sphere}

By accepting the societal provenance of archives, it is also possible to imagine archives not as tools of the state or of the majority, but as means of resistance by marginalized communities. By employing Nancy Fraser's (1992) concept of “subaltern counterpublics," one may re-envision archives as sites through which voiceless and marginalized communities such as the victims of Nogŭn-ri may counter the official narrative being imposed upon them. Fraser (1992) argues that members of subordinated social groups have repeatedly found it advantageous to constitute alternative publics where they formulate oppositional interpretations of their identities, interests and needs (p.67). Thus, it is important to move away from the traditional understanding and utilization of archives that caused exclusion and alienation of the socially marginalized. Instead, archives should provide a public sphere where people can openly participate in discussion, use information and "tease out their political interests and social needs with other participants" (Squires 2002, p.448) that are eventually articulated in and through multiple publics (a dominant public sphere and many subaltern counterpublics) for social change and equity. Such an approach would allow rich dialogues, counter discourses and contestation for egalitarian democratic society.

In order for archivists to serve in the formation of subaltern counterpublics, they need to reconsider their role. Above all, they need to recognize that they are not neutral custodians of records, but actively involved in the very process of making public history (Flinn, 2011). To do so, an activist archivist should go beyond the notion of "impartial archivist safe in her fortress" and look for ways in which alternative systems of memory become available and usable for socially marginalized and vulnerable communities (Findlay 2016 p.158). At the same time, archivists should recognize and reflect on the fact that they also come to the archives with their own values, experiences and education (Duff et al, 2013). Archiving, understood in this manner, requires considerable self-criticism and reflection.

Record-keeping is "inherently political” (Findlay, 2016), and even the most seemingly insignificant of the tasks in which archivists are engaged are linked to macro social and political concerns. Archivists should be "mindful of the exclusions, absence and silences in the archives" 
HONG | TOWARDS ARCHIVAL JUSTICE:THE CASE OF NOGǓN-RI MASSACRE DURINGTHE KOREAN WAR

(Duff et al 2013, p.330) which they can address by bringing in the voices of the marginalized themselves. Marginalized communities need to be recognized as meaningful creators of records themselves, while records need to be understood as being part of broader social structures and within their historical context (Cook 2013, p.110). By doing so, archivists can resist the marginalization of archival justice from archival institutions.

\section{A case study: The Nogŭn-ri massacre during the Korean War and Records for Social Memory}

The social justice implications of these three approaches - the societal provenance of archives, archives-as-process, and archival activism - are strongly evident in the discussion of the massacre by US soldiers of Korean civilians at Nogŭn-ri in July, 1950. The Nogŭn-ri massacre is one of many that occurred during the Korean War (1950-1953), which is frequently remembered, when it is remembered at all, in the English-speaking West as one of the US's good wars - as clear-cut conflict, involving the US leading the UN in a humanitarian intervention against Communist aggression. Within South Korea, by contrast, no discussion of the Korean War can escape political controversy. The war itself emerged from the 1945 division of the former Japanese colony into Soviet and US spheres, even though Koreans had substantially achieved their own liberation as the Korean People’s Republic under the socialist Yŏ Unhyŏng (1886-1947) before the arrival of US forces and when Soviet forces had only just begun their advance into the Korean peninsula (Cumings, 2010, pp. 103-118). Even before the invasion of the south by North Korean forces on Jun 25, 1950, the peninsula was scene to numerous atrocities, whether aided and abetted by the US Military Government in Korea, or committed by the nascent South Korean and North Korean regimes after 1948. The cities of northern Korea had a significant population of Protestant Korean bourgeoisie, resulting in clashes between students and the nascent communist regime in the border city of Sinŭiju in 1945 (Cathcart and Kraus, 2008). The rural south, by contrast, had become dominated by socialist and agrarian movements during the 1940s, and included many enthusiastic supporters of the Korean People's Republic who had liberated their home regions through leftist people's committees. The USbacked right-wing government of South Korea under Syngman Rhee inevitably came into conflict with this large left-leaning constituency, and committed numerous massacres of people suspected of leftism, most famously the state-led massacres in Cheju between 1947 and 1954 that resulted in the death of at least 30,000 people (Kim, 2014; Cumings 2010, pp. 121-131). After the outbreak of the war itself, UN forces, led by the US, committed numerous atrocities against civilians, whether through massive campaigns of aerial bombardment directed against civilian residences, or through the murder of civilian refugees by soldiers concerned with eliminating 
guerillas (Kim, 2004).

The Nogŭn-ri massacre, like other human rights violations from the Korean War, was remembered only by the survivors of the massacre for many decades, as outside of Korea it was swallowed up into the general amnesia concerning the Korean War, and was politically anathema to the right-wing dictatorships that governed South Korea until the late 1980s. The establishment of democracy in South Korea in 1987, and the freer conversation of the 1990s, began a process that allowed the victims of the massacre to speak openly about Nogŭn-ri. The official state archives of South Korea and the US were, however, found to be insufficient. Diverse private sources - oral histories of the war, diaries by US soldiers, North Korean soldiers and South Korean civilians - have been vital for both proving the fact of the massacre and for seeking redress for the victims. The archive has thus expanded in part through the demands of the survivors of the massacre, who have pushed to have their voices heard (Sinn, 2009). Rather than a static archive of a few authoritative sources, one may see the steady construction of a new archive responding to the call for social justice by the community itself as a counter-public sphere of survivors of the massacre and political activists have played a part in expanding and enriching the archives.

Nogŭn-ri is a village in the mountains of Ch'unchŏng province near Yŏngdong, in a region that had generally been dominated before the war by leftist people's committees, and had thus been at the receiving end of much state violence before and after the founding of the Republic of Korea in 1948. Halfway down the peninsula, on the Naktong river, it became the site of battles between the North Korean army and the US and South Korean soldiers during the Korean War. In late July 1950, as the region passed into the frontlines of the war, people leaving their home villages at the orders of the US military were met at Nogŭn-ri by US infantry and airforce under orders to treat all refugees as guerilla soldiers. Those who took shelter from aerial bombardment under a bridge in Nogŭn-ri were repeatedly shot over the space of several days by US soldiers who sought to kill anyone who might have survived their previous forays. Estimates for the number killed vary from 300 to 400 , and the few survivors were rescued by the advancing North Korean forces and allowed to return to their home villages (Hanley et al., 2001; Cumings, 2001).

The Nogŭn-ri massacre, so destructive to the lives of its survivors, was nevertheless hardly known outside of the village itself until the 1990s. The Korean War saw many atrocities against civilians by both sides of the conflict, but especially by US and South Korean forces. North and central Korean cities were destroyed by the US air force deploying carpet bombing and fire bombing, at great loss of life. The US forces, faced with fighting in a civil war against 
an often hostile population, treated ordinary civilians and refugees as suspected soldiers and militants, and pursued a scorched-earth and free-fire policy in many of the regions through which they passed (Kim, 2004). Nogŭn-ri, in other words, was not an unusual exception.

Until 1987, none of this could be spoken of freely in South Korea, and even since 1987 it has been a political fault line. Shortly after liberation, South Korea came under the control of US-backed authoritarian regimes. Except during the brief period of democratic government from 1960-1961, South Korea was governed by dictators, including Syngman Rhee (r. 19481960), Park Chung Hee (r. 1961-1979) and Chun Doo Hwan (r. 1980-1988). It was dangerous during these regimes to commemorate civilian victims of the war, let alone demand redress. The state had a range of tools at its disposal to prevent the public commemoration of atrocities committed by South Korean or UN forces. It could charge those who mentioned those atrocities with offenses against the National Security Law, and, through its control of the educational system, it pursued a narrow anti-communist education that restricted discussion of atrocities to those committed by, or falsely attributed to, North Korean forces. Those who took advantage of the brief period of democracy from 1960 to 1961 to press for justice for their loved ones received severe sanction by the authorities after the return to military rule (Suh, 2010; Wright, 2016, pp. 239-243). Kim (2010) argues that the victims of state violence during the Korean War were killed three times:

Metaphorically it can be said that South Korean authorities killed the Korean Warrelated victims and their families three times. First, the authorities killed the victims during the massacres (1948-1953). Second, they killed them again by suppressing their bereaved families' requests for truth and justice at a transformative political time in 1960. And finally, authorities killed them yet again by placing their family members under surveillance. (p. 541)

Authoritarian politics receded slowly following the establishment of democratic rule in 1988, as left-wing intellectuals actively sought to commemorate acts of violence committed during the Korean War whose memory had been so violently suppressed by the dictatorial regimes. Among these atrocities was the Nogŭn-ri massacre. As discussed by Sinn (2009), the massacre became known outside of the region through the publication, in 1994, of a novel concerning the massacre by one of its survivors. Yet the memory of the war expressed in this artistic form lacked the detail a traditional historian would ordinarily require - it wasn't clear which US regiment had been involved, nor the precise order of events - rather, it was a record of the subjective experience of a survivor. Researchers (including family members of the survivors) were able to use archival documents, such as regimental diaries, to prove that the 7 th cavalry 
HONG | TOWARDS ARCHIVAL JUSTICE:THE CASE OF NOGǓN-RI MASSACRE DURINGTHE KOREAN WAR

division was likely involved in the massacre. Other documents - contemporary North Korean newspaper accounts and scattered documents from the US military - drew a rough picture based on the eyewitness accounts of the South Korean survivors and of some veterans of the 7th cavalry regiment.

This growing body of evidence attracted the attention first of the South Korean public. Later, through journalist Sang-hun Choe, the correspondent for Associated Press in Seoul, it became known to the English-speaking public as well (Sinn, 2010). The work by Choe and his collaborators on the story was ultimately awarded a Pulitzer prize, but was politically controversial - with members of the US military arguing that it was based on faulty evidence, and the US officials investigating the atrocity taking what seemed to some to be an excessively conservative approach to the evidence. In 2000, Stars and Stripes published an article raising doubt on the testimony of three US soldiers who claimed to have witnessed the massacre, but who, according to the archival evidence, were unlikely to have been present (Sinn, 2009, pp. 9-10). These three possibly false testimonies were used to invalidate a far larger number of reliable eyewitnesses, especially South Koreans, but also several US soldiers who undoubtedly had been present on the scene (Sinn, 2009, pp. 9-10). Both South Korean and US governments published reports on the massacre in 2001. However, the US government ignored the collective memory of the villagers by appealing to the fallibility of memory, instead trying to restrict the investigation to the small number of official documents, which certainly also pointed to a massacre, but which tended to remove the US army from blame. Above all, the drafters of the US report claimed that any massacre that occurred was the result of confusion or unsanctioned actions on the part of the US soldiers, and was not part of any formal US policy (Sinn, 2009; Conway-Lanz, 2005). In South Korea itself, the collective memory of the survivors, which of course brought the massacre itself to broader public attention, has been considered much more important (Sinn, 2010). Considering the well-documented racism of many of the US officers and soldiers involved in the war, and their almost complete lack of Korean-language skills (Cumings, 2010, pp. 15-17), it is highly problematic to privilege US military records as uniquely neutral and accurate.

US military records, moreover, have been openly manipulated by the Pentagon and the US government in order to establish their official position - that the reports of massacres by US troops have been exaggerated and based on poor sources, and that such massacres as did occur were the result of US soldiers acting without official sanction. As Conway-Lanz (2005) points out, there is abundant testimony by US veterans of the war that they received oral orders to kill refugees who approached the US military's front-line - the fact that most of these orders did not leave a written record does not mean that they did not exist. Moreover, considerable written iJournal,Vol 5, No. I, Fall 2019 
HONG | TOWARDS ARCHIVAL JUSTICE:THE CASE OF NOGǓN-RI MASSACRE DURING THE KOREANWAR

documentation reflecting a formal policy to have US planes bomb and strafe civilians, or have US infantry fire on refugees, has been uncovered (Sinn, 2009, 11-12). Notably, after the 2001 US report had been completed, Conway-Lanz (2005) uncovered an official letter written on July 26, 1950 by the then US ambassador to South Korea, John J. Muccio, in which the ambassador described the shooting of civilian refugees travelling south as the official policy of the US military and as necessary to combat guerilla infiltration from North Korea. Tellingly, as Hanley (2010) notes, this "smoking gun" was deliberately excluded by the drafters of the 2001 US report on the Nogŭn-ri incident, as it absolutely contradicted the official US position.

The growing archive of the massacre, in fact, can be seen as developing through the confluence of diverse political, social and cultural forces in South Korea, the US and elsewhere. The late 1990s and the early 2000s, when the South Korean government actively pursued the discussion of the Nogŭn-ri massacre, was an unusual period in South Korean history. A decade after the end of dictatorial rule, the South Korean public elected two left-of-center presidents in a row, Kim Dae-jung (1998-2003) and Rho Moo-hyun (2003-2008), whose administrations encouraged a broader reconsideration of the abuses of the past (Kim, 2010), forming a number of truth commissions to explore past abuses, including, for instance, a commission to explore the massacre in Cheju during the late 1940s and early 1950s (Kim, 2014). The succeeding rightleaning governments of Lee Myung-bak (2008-2013) and Park Geun hye (2013-2017) were actively hostile to such investigations (Kim, 2017). Nevertheless, the archive of the Nogŭn-ri massacre has continued to grow at the impetus of researchers, journalists, survivors, and the broader public. Indeed, the memory of Korean War atrocities has, to a certain extent, been depoliticized, as memorial sites to these atrocities have become increasingly promoted as tourist sites by provincial and municipal governments (Hong, 2015; Wright, 2015; Choi, 2008).

Donghee Sinn (2010), a South Korean archivist now based in the United States, has pointed out that military documents, survivor testimony, diaries by US soldiers and North Korean soldiers, forensic evidence, and indeed later discussion of the massacre have all played a role in shaping the memory of the massacre. The very debate concerning the war has resulted in the construction of a growing body of knowledge, much of it online. Thus, the archive has become accessible to the broader community - a visible example of an archive in the process of construction. The case reveals clearly the social forces underlying the construction of an archive, and the role played by dissident actors operating in tension with the interests of the state.

\section{Conclusion}

Archives, as Stoler (2002) points out, are not inert storehouses for information, but rather 
constantly developing entities in their own right. Archivists concerned with social justice need to intervene in this process of archive construction, "to ensure that the voiceless population is not a silent witness, but a full partner in the record-creating process" (Jimerson, 2007, p. 276). This paper demonstrates an example of social activism resulting in the construction of an archive, and the role of this developing archive in the discussion of a massacre committed by the US military during the Korean War. The archive described in this paper is one characterized by constant growth and development, and also one which may be seen have a societal provenance. These are features of this particular archive, and also aspects of any archive that an archivist concerned with social activism needs to understand and foster.

In the case of Nogŭn-ri, a narrow view of the archive, privileging only official US military sources, risks revictimizing the survivors of the massacre, whose own stories must be included within the public record of the event. Ultimately, archives - including official government archives - share a broader societal provenance. By fully embracing the societal provenance of the archive, and the responsibility of the archivist to the community as a whole, it is possible, as in the case of Nogŭn-ri, to make archives a tool of justice, truth, and reconciliation.

\section{References}

Anderson, J. (2013). Anxieties of Authorship in the Colonial Archives. In Chris, C., \& Cerstner, D.A., (Eds). Media Authorship. New York: Routledge.

Cathcart, A., \& Kraus, C. (2008). Peripheral influence: The Sinŭiju student incident of 1945 and the impact of Soviet occupation in North Korea. The Journal of Korean Studies, 13(1), $1-27$.

Choi, S. (2008). Silencing survivors' narratives: Why are we "again" forgetting the No Gun Ri story? Rhetoric and Public Affairs, 11(3), 367-388.

Conway-Lanz, S. (2005). Beyond No Gun Ri: Refugees and the United States Military in the Korean War. Diplomatic History, 29 (1), 49-81.

Cook, T. (2013). Evidence, Memory, Identity and Community: Four Shifting Archival Paradigms. Archival Science, 13, 95-120. 
HONG | TOWARDS ARCHIVAL JUSTICE:THE CASE OF NOGǓN-RI MASSACRE DURINGTHE KOREAN WAR

Cook, T. (1997). What is Past is Prologue: A History of Archival Ideas Since 1898 and the Future Paradigm Shift. Archivaria, 43, 17-63.

Cumings, B. (2001). Occurrence at Nogŭn-ri Bridge: An Inquiry into the History and Memory of a Civil War. Critical Asian Studies, 33(4), 509-526.

Cumings, B. (2010). The Korean War: A History. New York: Modern Library.

Derrida, J. (1996). Archive Fever: A Freudian Impression. Chicago: University of Chicago Press.

Douglas, J. (2017). "Origins and Beyond: The Ongoing Evolution of Archival Ideas about Provenance." In MacNeil, H., \& Eastwood, T. (eds). Currents of Archival Thinking. Santa Barbara: Libraries Unlimited, 25-52.

Duff, M.W., Flinn, A., Suurtamm, K. E., \& Wallace, D.A. (2013). Social Justice Impact of Archives: A Preliminary Investigation. Archival Science, 13, 317-348.

Duff, M.W., \& Harris, V. (2002). Stories and Names: Archival Description as Narrating Records and Constructing Meanings. Archival Science, 3, 275-280.

Findlay, C. (2016). Archival activism. Archives and Manuscripts, 44(3), 155-159.

Flinn, A. (2011). Archival Activism: Independent and Community-led Archives, Radical Public History and the Heritage Profession. InterActions: UCLA Journal of Education and Information Studies, 7, retrieved from https:/escholarship.org/uc/item/9pt2490x.

Hanley, C.J. (2010). No Gun Ri. Critical Asian Studies, 42(4), 589-622.

Hanley, C. J., Choe, S. H., \& Mendoza, M. (2001). The Bridge at No Gun Ri: A Hidden Nightmare from the Korean War. New York: Macmillan.

Hong, S. C. (2015). Silenced in memoriam: Consuming memory at the Nogŭnri Peace Park. Cross-Currents: East Asian History and Culture Review, (14), 178-203.

Jimerson, R.C. (2007). Archives for All: Professional Responsibility and Social Justice. The ijournal,Vol 5, No. I, Fall 2019 
American Archivist, 70 (2), 252-281.

Ketelaar, E. (1999). Archivalization and Archiving. Archives and Manuscripts, 27, 54-61.

Ketelaar, E. (2009). A Living Archive, Shared by Communities of Records. In Bastian, J., \& Alexander B. (Eds). Community Archives: the Shaping of Memory. London: Facet, 109-132.

Kim, D. C. (2004). Forgotten War, Forgotten Massacres - The Korean War (1950-1053) as Licensed Mass Killings. Journal of Genocide Research, 6(4), 523-544.

Kim, D.C. (2010). The Long Road toward Truth and Reconciliation: Unwavering Attempts to Achieve Justice in South Korea. Critical Asian Studies, 42(4), 525-552.

Kim, H.J. (2014). The Massacre at Mt. Halla: Sixty Years of Truth Seeking in South Korea. Ithaca: Cornell University Press.

Kim T. (May 23, 2017). Sarajin kwagŏsa kwallyŏn wiwŏnhoe dŭl [Disappearing Committees concerning Historical Events]. Chugan Kyŏnghyang, retrieved from m.weekly.khan.co.kr.

Lee, K. R. (2015). Past Affairs-Related Collective Memories and the Archival Justice: The Contemporary Rebuilding of the Archive on the Truth and Reconciliation Committee. The Korean Journal of Archival Studies, 46, 5-44.

Nesmith, T. (2002). Seeing Archives: Postmodernism and the Changing Intellectual Place of Archives. American Archivist, 65, 24-41.

Nesmith, T. (1999). Still Fuzzy but More Accurate: Some Thoughts on the 'Ghost' of the Archival Theory." Archivaria , 47, 136-150.

Sinn, D. (2010). Room for archives? Use of archival materials in No Gun Ri research. Archival Science, 10(2), 117-140.

Sinn, D. (2009). Building Collective Memory of No Gun Ri: Creating Archives as Memory. Conference Proceedings of International Federation of Library Associations (IFLA) Conference 2009. Milan Italy, August 23-27. 
Stoler, A. L. (2002). Colonial archives and the arts of governance. Archival Science, 2(1-2), 87 109. DOI:10.1007/BF02435632

Suh, J. (2010). Truth and Reconciliation in South Korea: Confronting War, Colonialism and Intervention in the Asia Pacific. Critical Asian Studies, 42(4), 503-524.

Wallace, D. A. (2017). Archives and Social Justice. In MacNeil, H., \& Eastwood, T. (eds). Currents of Archival Thinking. Santa Barbara, California: Libraries Unlimited, 271-298.

Wright, B. (2015). Politicidal violence and the problematics of localized memory at civilian massacre sites: The Cheju 4.3 Peace Park and the Kŏchang Incident Memorial Park. Cross-Currents: East Asian History and Culture Review, 4(1), 151-180.

Wright, B. (2016). Civil war, politicide, and the politics of memory in South Korea, 1948-1961 (Doctoral dissertation, University of British Columbia). 